DOI: https://doi.org/10.32838/2523-4803/70-1-13

удК 369.032:339.13(477)

\title{
Сидорчук О.Г.
}

доктор наук $з$ державного управління, доцент кафедри державного управління, Львівський регіональний інститут державного управління

Національної академії державного управління при Президентові України

ORCID: https://orcid.org/0000-0002-7078-1557

\section{Клепанчук О.Ю.}

кандидат економічних наук,

доцент кафедри державних та місцевих фінансів,

Львівський національний університет імені Івана Франка

ORCID: https://orcid.org/0000-0001-7764-614X

\section{Sydorchuk Orystlava}

Lviv Regional Institute of Public Administration

National Academy for Public Administration under the President of Ukraine

Klepanchuk Olga

Ivan Franko National University of Lviv

\section{ЦІЛІ ДЕРЖАВНОГО РЕГУЛЮВАННЯ ВНУТРІШНЬОГО РИНКУ ПРАЦІ \\ ЗА УМОВ ЗАПРОВАДЖЕННЯ ІНСТИТУЦІЙНИХ РЕФОРМ}

\begin{abstract}
Дослідження присвячене обтрунтуванню цільових орієнтирів інституційного регулювання розвитку внутрішнього ринку праці, зокрема структурної збалансованості розвитку його сегментів та їх ефективної гармонізованої взаємодії за умов запровадження інституційних реформ. Показано, щуо ринок праці є похідним від ринку ресурсів, значною мірою впливаючи на рівень розвитку інших видів і типів внутрішніх ринків. Проаналізовано показники ринку праці щзодо економічно активного/ неактивного населення, регіонального розподілу робочої сили. Запропоновано класифікачійний поділ інституиійного управління суспільним розподілом на внутрішньому ринку праці. Розкрито $і$ деталізовано основні функиії ринку праці. Продемонстровано характерні особливості державного регулювання внутрішнього ринку праці, щзо забезпечують збалансований проактивний розвиток $і$ гармонізовану взаємодію ринкових сегментів.

Ключові слова: державне регулювання, трудові ресурси, сочіально-трудові відносини, інституиійні механізми, зайнятість, конкурентоспроможність.
\end{abstract}

Постановка проблеми. Основні завдання державного регулювання внутрішнього ринку праці визначають системний та комплексний вплив як на стимулювання соціально-економічного розвитку, так і на сам розвиток з упровадженням структурних змін та інституційних реформ як ключових засобів його регулювання. Здатність ринку праці вчасно й адекватно реагувати на динамічні процеси соціально-економічних перетворень є визначальною умовою побудови ефективного ринкового механізму вирішення соціальних суперечностей у царині регулювання соціальнотрудових відносин. Метою державного регулювання внутрішнього ринку $є$ реалізація пріоритетів державної економічної політики та забезпечення структурнозбалансованого ефективного розвитку внутрішнього ринку за рахунок активного розвитку окремих його сегментів та їх ефективної гармонізованої взаємодії. Необхідність включення до цільових орієнтирів дер- жавної політики розвитку внутрішнього ринку праці структурної збалансованості розвитку його сегментів та їх ефективної гармонізованої взаємодії потребує впровадження дієвих механізмів стимулювання відтворювальних процесів, активного та ефективного розвитку структурних сегментів ринку і зумовлює актуальність цього дослідження.

Аналіз останніх досліджень і публікацій. Проблеми інституційного регулювання ринку праці вже довгий час знаходяться в полі зору багатьох економістів. Зокрема, пошуку нових підходів до державної політики зайнятості, територіального управління зайнятістю i безробіттям присвячено дослідження В.А. Ландсмана, який розробляв методологічні засади державного регулювання ринку праці [3]; В.О. Рубежанської, яка присвятила дослідження функціональним аспектам державного регулювання ринку праці на регіональному рівні і запропонувала адаптивну 
модель управління [6]; К.В. Дубича, який здійснив і докладно описав PESTL-аналіз факторів тінізації ринку праці та зайнятості населення в Україні [2]. Питання державного регулювання i макроструктури зайнятості розглядали В.І. Приймак, Д. Скорупка, які визначили низку завдань інституційного управління ринком праці і запропонували методи математичного моделювання для їх вирішення [4]. Різні аспекти розвитку внутрішнього ринку праці з погляду на євроінтеграційні аспекти вивчалися І.Б. Юрчик, І.Ф. Гнибіденком, Н.Б. Кузнєцовою, Ю.М. Маршавіним [1;8]. Незважаючи на доволі великий науковий інтерес до питань інституційного регулювання ринку праці, все ще наявні прогалини в досліджені окремих правових, економічних, організаційних і соціальних аспектів означеної проблеми. Аналіз джерел засвідчує також відсутність наукової єдності в позиціях розуміння головної мети та завдань державного регулювання, які найчастіше розглядаються у загальноекономічному контексті або з урахуванням спеціалізації та особливостей регулювання окремих секторів чи галузевих ринків. Ринкові перетворення потребують розроблення довгострокової політики державного управління розвитком внутрішнього ринку праці та обгрунтування відповідних інструментів.

Формулювання цілей статті. Мета статті - виявити цілі державного регулювання внутрішнього ринку праці в контексті запровадження структурних змін та інституційних реформ як основних засобів державного регулювання.

Виклад основного матеріалу. У загальному розумінні ринок являє собою сукупність економічних і правових взаємовідносин щодо купівлі-продажу товарів. Ринок праці $є$ похідним від ринку ресурсів, значною мірою впливаючи на рівень розвитку інших видів i типів внутрішніх ринків. Підгрунтям формування ринку праці $є$ товарна форма робочої сили. У загальному вигляді це означає, що працівники як власники робочої сили пропонують, тоді як власники капіталу задовольняють власний попит на неї. Відповідно, співвідношення попиту і пропозиції на робочу силу формує ії ринкову вартість, яка набуває, зрештою, грошової форми у вигляді заробітної плати.

Специфічність ринку праці проявляється, насамперед, через віддзеркалення купівлі-продажу робочої сили через соціально-економічні та трудові відносини. На ринкову пропозицію робочої сили впливають як загальний соціально-економічний стан держави (зокрема, рівень мінімальної і середньої заробітної плати, а також рівень заробітної плати за окремими категоріями працівників), так і демографічні показники (чисельність і вікова структура населення). Водночас ринковий попит на робочу силу, враховуючи ці критерії залежності, оперує також поняттями взаємозамінних чинників виробництва (зокрема, основних промислово-виробничих фондів). Заробітна плата як основний інструмент регулювання описаних вище взаємовідносин купівлі-продажу залежить від комплексу чинників, основним з яких є співвідношення попиту і пропозиції. Водночас на рівень оплати праці значний вплив має розвиток механізмів інституційного регулювання зайнятості населення.

До основних сфер управлінського впливу на ринку праці зазвичай відносять процеси працевлаштування, підготовки (перепідготовки) працівників, обіг робочої сили [8]. Взаємодія з іншими ринками проявляється через залучення носіїв робочої сили (працівників) до виробничо-господарських структур на товарних ринках і отримання оплати за працю на фінансовому ринку. Таку взаємодію можна вважати специфічним інструментом ринку праці, який покликаний узгоджувати ціну одиниці праці та інші умови взаємодії найманого працівника 3 працедавцем.

Визначальним показником ринку праці вважається частка економічно активного/неактивного населення (у більш вузькому розумінні прийнято оперувати поняттями зайнятих і безробітних [6]). Зазначимо, що економічно активне населення $є$ складником трудових ресурсів. До цієї категорії відноситься працездатне населення, фізично й розумово здатне до провадження корисної діяльності (табл. 1). Залучення робочої сили до виробничих відносин тісно пов'язане з можливістю iї відтворення як суспільного продукту, що включає іiі формування, розподіл і перерозподіл.

Таблиця 1

Стан робочої сили в Україні у 2019 р. [5]

\begin{tabular}{|c|c|}
\hline Показник & Розподіл \\
\hline \multirow{3}{*}{$\begin{array}{l}\text { Зайняте населення, } \\
\text { тис осіб }\end{array}$} & 15 років і старше - 16,7 млн осіб \\
\hline & $15-70$ років $-16,6$ млн осіб \\
\hline & працездатного віку - 15,9 млн осіб \\
\hline \multirow[t]{3}{*}{ Рівень зайнятості, \% } & 15 років і старше $-51,9 \%$ \\
\hline & $15-70$ років $-58,3 \%$ \\
\hline & працездатного віку - 67,8\% \\
\hline \multirow{3}{*}{$\begin{array}{l}\text { Безробітне населення } \\
\text { (за методологією } \\
\text { МОП), тис осіб }\end{array}$} & 15 років і старше - 1462 тис осіб \\
\hline & 15-70 років -1462 тис осіб \\
\hline & працездатного віку - 1461 тис осіб \\
\hline \multirow{3}{*}{$\begin{array}{l}\text { Рівень безробіття } \\
\text { (за методологією } \\
\text { МОП), \% }\end{array}$} & 15 років і старше $-8,0 \%$ \\
\hline & $15-70$ років $-8,1 \%$ \\
\hline & працездатного віку - 8,4\% \\
\hline
\end{tabular}

Інституційне управління суспільним розподілом на внутрішньому ринку праці доцільно класифікувати за вертикальними рівнями структури економіки, організаційно-економічними формами функціонування, формами та галузями суспільного виробництва. За ознакою структурованості економіки внутрішній ринок праці поділяється на три рівні. Перший характеризується наявністю значною кількості економічно самостійних господарських суб'єктів (підприємства та фізичні особи - підприємці). Наступний рівень являє собою розгалужену ринкову надбудову, що містить галузеві ознаки. Верхній рівень охоплює галузі економіки, об'єднані спільним рівнем суспільного поділу праці. Вертикальна структура організації виробництва дає змогу візуалізувати міру розкриття техніко-еконо- 
мічних характеристик видів праці на кожному з описаних рівнів.

Раціональне формування і розподіл трудових ресурсів вимагають використання науково обгрунтованої системи балансів, які відображають окремі аспекти функціонування внутрішнього ринку праці й ураховують специфіку регіонального розвитку трудових ресурсів (табл. 2). Слід зазначити, що рівень безробіття працездатного населення України щороку скорочується, що позитивно впливає на показники його економічної активності.

Системною метою інституційного регулювання внутрішнього ринку праці $є$ вплив на його функції (табл. 3), які тісно взаємодіють і взаємодоповнюють одна одну. Використання механізмів конкуренції стимулює ринок до ефективнішого використання трудових ресурсів, чим забезпечується підвищення прибутковості господарських процесів та заохочення носіїв трудових ресурсів до підвищення свого професійнокваліфікаційного рівня.

За економічною сутністю регіональний ринок праці $\epsilon$ сукупністю високолокалізованих соціально-економічних відносин зі специфічними територіальними особливостями [6]. Отже, інституційний вплив на розвиток регіональних ринків праці має враховувати

Таблиця 2

Характеристика регіонального розподілу робочої сили в Україні (вік - 15-70 років) у 2018-2019 рр. [7]

\begin{tabular}{|c|c|c|c|c|c|c|c|c|}
\hline \multirow{2}{*}{ Регіон } & \multicolumn{2}{|c|}{ Зайняті (тис осіб) } & \multicolumn{2}{|c|}{ Рівень зайнятості (\%) } & \multicolumn{2}{|c|}{ Безробітні (тис осіб) } & \multicolumn{2}{|c|}{ Рівень безробіття (\%) } \\
\hline & 2018 & 2019 & 2018 & 2019 & 2018 & 2019 & 2018 & 2019 \\
\hline Україна & 16408,5 & 16627,6 & 57,2 & 58,3 & 1549,3 & 1461,8 & 8,6 & 8,1 \\
\hline Вінницька & 654,3 & 662,9 & 56,9 & 58,2 & 72,0 & 68,7 & 9,9 & 9,4 \\
\hline Волинська & 371,8 & 381,1 & 49,6 & 51,0 & 47,6 & 45,1 & 11,3 & 10,6 \\
\hline Дніпропетровська & 1409,4 & 1421,2 & 58,9 & 59,8 & 117,4 & 114,8 & 7,7 & 7,5 \\
\hline Донецька & 740,9 & 748,6 & 50,0 & 51,0 & 120,6 & 116,8 & 14,0 & 13,5 \\
\hline Житомирська & 519,0 & 523,5 & 57,8 & 58,7 & 59,1 & 54,9 & 10,2 & 9,5 \\
\hline Закарпатська & 503,7 & 510,1 & 54,7 & 55,5 & 54,5 & 49,4 & 9,8 & 8,8 \\
\hline Запорізька & 733,5 & 743,8 & 56,8 & 58,2 & 79,2 & 75,8 & 9,7 & 9,2 \\
\hline Івано-Франківська & 565,4 & 574,6 & 55,6 & 56,6 & 47,7 & 43,9 & 7,8 & 7,1 \\
\hline Київська & 755,5 & 774,0 & 58,5 & 59,5 & 49,3 & 47,2 & 6,1 & 5,7 \\
\hline Кіровоградська & 382,4 & 386,8 & 54,7 & 56,0 & 49,8 & 47,0 & 11,5 & 10,8 \\
\hline Луганська & 300,0 & 305,3 & 57,2 & 59,1 & 53,3 & 48,3 & 15,1 & 13,7 \\
\hline Львівська & 1062,2 & 1076,0 & 56,9 & 57,9 & 77,2 & 74,0 & 6,8 & 6,4 \\
\hline Миколаївська & 497,7 & 500,9 & 58,3 & 59,2 & 52,5 & 50,6 & 9,5 & 9,2 \\
\hline Одеська & 1004,5 & 1022,3 & 57,3 & 58,4 & 64,8 & 61,7 & 6,1 & 5,7 \\
\hline Полтавська & 580,9 & 591,3 & 55,1 & 56,6 & 72,5 & 70,2 & 11,1 & 10,6 \\
\hline Рівненська & 475,6 & 489,0 & 57,0 & 58,8 & 50,5 & 43,6 & 9,6 & 8,2 \\
\hline Сумська & 489,0 & 494,3 & 58,8 & 60,2 & 45,5 & 40,3 & 8,5 & 7,5 \\
\hline Тернопільська & 411,8 & 418,8 & 52,8 & 54,0 & 46,8 & 45,3 & 10,2 & 9,8 \\
\hline Харківська & 1265,3 & 1270,6 & 61,8 & 62,5 & 67,3 & 62,8 & 5,1 & 4,7 \\
\hline Херсонська & 449,5 & 456,2 & 57,7 & 59,1 & 51,3 & 48,5 & 10,2 & 9,6 \\
\hline Хмельницька & 525,6 & 531,1 & 56,2 & 57,3 & 46,7 & 45,5 & 8,2 & 7,9 \\
\hline Черкаська & 524,0 & 531,9 & 57,8 & 59,3 & 53,2 & 46,4 & 9,2 & 8,0 \\
\hline Чернівецька & 384,9 & 395,1 & 57,5 & 59,1 & 31,9 & 29,1 & 7,7 & 6,9 \\
\hline Чернігівська & 431,1 & 436,3 & 57,4 & 59,0 & 50,8 & 48,8 & 10,5 & 10,1 \\
\hline м. Київ & 1370,5 & 1381,9 & 62,7 & 63,2 & 87,8 & 83,1 & 6,0 & 5,7 \\
\hline
\end{tabular}

Таблиця 3

Функції внутрішнього ринку праці

\begin{tabular}{|l|l|}
\hline \multicolumn{1}{|c|}{ Функція } & \multicolumn{1}{c|}{ Функціональне наповнення } \\
\hline Регулятивна & - Регулювання пропорцій суспільного виробництва та надлишку трудових ресурсів \\
\hline Розподільча & - Розподіл робочої сили за регіонами, галузями економіки, професіями, формами зайнятості \\
& - Розподіл доходів і заробітної плати, встановлення рівноважної ставки оплати праці \\
\hline Організаційна & - Організація співпраці роботодавців і найманого персоналу \\
\hline Ціноутворююча & - Встановлення рівноваги між попитом і пропозицією робочої сили \\
\hline Оздоровлююча & - Конкурентне усунення економічно неефективного виробництва \\
\hline Посередницька & - Конкурентна перевага працівників із високими якісними показниками людського потенціалу \\
\hline Селективна & - Встановлення зв’язку між роботодавцями і найманими працівниками \\
\hline Інноваційна & - Селекція найбільш затребуваних професій \\
\hline
\end{tabular}


особливості попиту і пропозиції територіально-адміністративних утворень і грунтуватися на використанні адекватних методів регулювання його кон'юнктури.

Структурна перебудова економіки України починалася в умовах жорстко регламентованого ринку праці й супроводжувалася значною кількістю кризових явищ. Випереджальне зростання робочої сили на тлі суттєвого підвищення продуктивності призвело до стрімкого збільшення безробіття. Отже, виникла нагальна необхідність формування гнучкого ринку праці, який би найефективніше міг пристосуватися до цілей економічної структуризації. Розвиток гнучкого ринку праці тісно пов'язаний із глобалізаційними тенденціями у світовій економіці та ефективним поглибленням розподілу праці. Хоча не можна однозначно стверджувати, що гнучкий ринок праці може повністю подолати явища безробіття, він дає змогу пом'якшити його наслідки для економіки держави, а також сприяти зайнятості низько конкурентоспроможних верств населення завдяки впровадженню гнучких форм зайнятості. Гнучкість ринку праці передбачає:

- оперативне реагування на кон'юнктурні зміни змінення попиту, пропозиції, цін;

- територіальну та професійну мобільність трудових ресурсів;

- гнучке регулювання обсягів виробництва, застосування інноваційних форм управління кадрами;

- різноманітність методів і форм соціальної допомоги;
- різноманітність методів і форм зайнятості.

Кінцевою метою ринку праці $є$ задоволення професійно-трудових інтересів економічно активних громадян і досягнення максимально повної зайнятості. Цілеспрямоване інституційне регулювання процесів соціалізації ринку праці об'єктивно пов'язане із забезпеченням повної, продуктивної та ефективної зайнятості населення (табл. 4). Об'єктами державного регулювання $є$ внутрішній ринок праці як система та його сектори як підсистеми, економічні та соціально-економічні, ринкові процеси, що відбуваються на внутрішньому ринку та не можуть бути повною мірою вирішені внутрішніми процесами ринкового регулювання та саморегулювання, такі як відтворювальні процеси чи процеси взаємодії.

До цілей державного регулювання внутрішнього ринку праці можна віднести досягнення збалансованого зростання економічної системи, вирішення проблем соціально-економічного розвитку та забезпечення ефективного ринкового функціонування, визначення та реалізацію пріоритетних напрямів державної політики. Отже, основна ціль державного регулювання зумовлюється особливостями трудових ресурсів як об’єкта регулювання, проблемами його розвитку та можливими методами їх вирішення. Раціональне використання трудових ресурсів дасть змогу забезпечити стабільний економічний розвиток, конкурентоспроможність вітчизняних трудових ресурсів та соціально спрямований розвиток суспільства.

Таблиця 4

Особливості державного регулювання внутрішнього ринку праці

\begin{tabular}{|c|c|}
\hline $\begin{array}{c}\text { Елементи внутрішнього ринку праці } \\
\text { та особливості регулювання }\end{array}$ & $\begin{array}{c}\text { Позитивні ефекти від врахування особливостей } \\
\text { державного регулювання внутрішнього ринку праці }\end{array}$ \\
\hline $\begin{array}{l}\text { Мета: реалізація пріоритетів державної економічної } \\
\text { політики та забезпечення структурно збалансованого } \\
\text { ефективного розвитку внутрішнього ринку }\end{array}$ & $\begin{array}{l}\text { Досягнення збалансованого зростання економічної системи, } \\
\text { вирішення проблем соціально-економічного розвитку та } \\
\text { забезпечення ефективного ринкового функціонування }\end{array}$ \\
\hline $\begin{array}{l}\text { Завдання: } \\
\text { - впровадження структурних змін та інституційних реформ } \\
\text { як ключових засобів регулювання внутрішнього ринку }\end{array}$ & - зростання показників соціально-економічного розвитку \\
\hline $\begin{array}{l}\text { - структурне збалансування розвитку сегментів } \\
\text { внутрішнього ринку праці та їх ефективної взаємодії }\end{array}$ & - структурно збалансований розвиток внутрішнього ринку праці \\
\hline $\begin{array}{l}\text { - впровадження дієвих механізмів стимулювання } \\
\text { відтворювальних процесів сегментів ринку }\end{array}$ & - зростання продуктивності та відтворювальних процесів \\
\hline $\begin{array}{l}\text { Об’єкти: } \\
\text { сегменти ринкової структури; процеси взаємодії між } \\
\text { структурними елементами внутрішнього ринку праці; } \\
\text { процеси відтворення та розвитку трудових ресурсів }\end{array}$ & $\begin{array}{l}\text { Зростання ефективності соціально-економічного розвитку } \\
\text { внаслідок збалансування процесів взаємодії між структурними } \\
\text { сегментами ринку, активування внутрішньоринкових } \\
\text { відтворювальних процесів }\end{array}$ \\
\hline $\begin{array}{l}\text { Суб'єкти: } \\
\text { особливостями державного регулювання ВР є } \\
\text { необхідність надання державою певних механізмів } \\
\text { із регулювання ринкових процесів та відносин } \\
\text { внутрішньоринковим об’єднанням, асоціаціям }\end{array}$ & $\begin{array}{l}\text { Упровадження механізмів державно-приватного партнерства; } \\
\text { посилення внутрішньоринкових саморегуляторних функції }\end{array}$ \\
\hline $\begin{array}{l}\text { Принципи: } \\
\text { - принцип системності впливу державного регулювання }\end{array}$ & $\begin{array}{l}\text { - системність та водночас адресність дій та заходів державного } \\
\text { регулювання }\end{array}$ \\
\hline $\begin{array}{l}\text { - принцип структурної збалансованості розвитку окремих } \\
\text { сегментів у загальній системі внутрішнього ринку; }\end{array}$ & - структурна збалансованість розвитку \\
\hline - принцип комплексності & - комплексність поєднання методів прямого та непрямого впливу \\
\hline - принцип інституціоналізму та реформаторства & - активне провадження структурних змін та інституційних реформ \\
\hline - принцип пріоритетів права власності & $\begin{array}{l}\text { - активізація інвестиційних процесів та відтворення на } \\
\text { внутрішньоринкових сегментах }\end{array}$ \\
\hline
\end{tabular}




\begin{tabular}{|c|c|}
\hline - принцип конституційності, законності & $\begin{array}{l}\text { - дотримання норм права, зменшення частки тіньової економіки, } \\
\text { прозорість економічного розвитку }\end{array}$ \\
\hline - принцип балансу економічних інтересів & $\begin{array}{l}\text { - формування ефективного балансу між виробництвом та } \\
\text { споживанням; недопущення монополізації ринків; дотримання } \\
\text { прав та свобод суб'єктів ринкових відносин }\end{array}$ \\
\hline $\begin{array}{l}\text { Функції: } \\
\text { - цільова функція }\end{array}$ & $\begin{array}{l}\text { - окреслює основні цілі напрями та пріоритети державного } \\
\text { регулювання внутрішнього ринку }\end{array}$ \\
\hline - нормативна функція & $\begin{array}{l}\text { - забезпечує повноту законодавчої бази та їі вдосконалення } \\
\text { актів відповідно до динамічних ринкових змін }\end{array}$ \\
\hline - регуляторна функція & $\begin{array}{l}\text { - забезпечує ефективне функціонування та розвиток } \\
\text { внутрішнього ринку }\end{array}$ \\
\hline - інституційна функція & $\begin{array}{l}\text { - ініціювання інституційних перетворень та структурних } \\
\text { реформ, визначення пріоритетних напрямів структурно- } \\
\text { галузевої політики }\end{array}$ \\
\hline - стимулююча функція & $\begin{array}{l}\text { - впровадження державної політики стимулювання } \\
\text { процесів відтворення та розвитку, зростання рівня } \\
\text { конкурентоспроможності продукції }\end{array}$ \\
\hline - мотиваційна функція & $\begin{array}{l}\text { - мотивування активізації внутрішньоринкових механізмів } \\
\text { конкурентного розвитку }\end{array}$ \\
\hline - соціальна функція & $\begin{array}{l}\text { - реалізація соціальних компенсаційних програм стимулювання } \\
\text { та розвитку }\end{array}$ \\
\hline - контрольна функція & $\begin{array}{l}\text { - збалансованість ринкових та інституційних процесів } \\
\text { відповідно до законодавчих норм та стандартів }\end{array}$ \\
\hline $\begin{array}{l}\text { Механізм: особливістю механізму державного } \\
\text { регулювання ВР є системний та комплексний вплив як на } \\
\text { стимулювання розвитку, так і на сам розвиток }\end{array}$ & $\begin{array}{l}\text { Стимулювання процесів ефективного економічного розвитку } \\
\text { внаслідок розбудови та розвитку внутрішнього ринку як базису } \\
\text { економічної системи держави }\end{array}$ \\
\hline $\begin{array}{l}\text { Інструменти: особливістю є пріоритетність методів та } \\
\text { інструментів непрямого опосередкованого впливу }\end{array}$ & $\begin{array}{l}\text { Зростання ефективності та адресності методів та інструментів } \\
\text { державної політики в регулюванні }\end{array}$ \\
\hline
\end{tabular}

Висновки. Узагальнюючи, зазначимо, що головною метою державного регулювання внутрішнього ринку праці є системний та комплексний вплив як на стимулювання його розвитку, так і на сам розвиток, що реалізується з упровадженням структурних змін та інституційних реформ як основних засобів державного регулювання. Відповідно до зазначених особливостей, інституційне регулювання ринку праці $\epsilon$ цілеспрямованим системним і комплексним впливом, що здійснюється з упрова- дженням структурних змін та інституційних реформ та системним застосуванням комплексу методів та інструментів прямої та опосередкованої дії. Такий вплив спрямовується на забезпечення ефективного збалансованого проактивного розвитку та регулювання гармонізованого взаємозв'язку та взаємодії ринкових сегментів, що забезпечить сталий активний економічний розвиток внутрішнього ринку праці, його структурних елементів та соціально-економічний розвиток країни у цілому.

\section{Список літератури:}

1. Ринок праці України: перспективи євроінтеграції : монографія / І.Ф. Гнибіденко та ін. Київ : ДКС центр, 2012. 246 c.

2. Дубич К.В. Фактори тінізації ринку праці України. Державне управління: удосконалення та розвиток. 2017. № 10. URL : http://www.dy.nayka.com.ua/?op=1\&z=1132. (дата звернення: 20.01.2020).

3. Ландсман В.А. Методологічні підходи до державного регулювання ринку праці. Теорія та практика державного управління. 2012. № 4(39). С. 338-345.

4. Приймак B.I., Скорупка Д. Економіко-математичні методи та моделі в управлінні ринком праці. Економіка: реалії часу. 2013. № 2(7). С. 6-15.

5. Ринок праці в 2019 році / Державна служба статистики України. URL : http://www.ukrstat.gov.ua/druk/publicat/ kat_u/publ11_u.htm. (дата звернення: 21.01.2020).

6. Рубежанська В.О. Функції та ключові напрями управління регіональним ринком праці. Економіка $i$ суспільство. 2016. Вип. 7. С. 582-589.

7. Ситуація на ринку праці та результати діяльності державної служби зайнятості у 2019 році : аналітична та статистична інформація / Державна служба зайнятості. URL : https://www.dcz.gov.ua/analitics/68 (дата звернення: 21.01.2020).

8. Юрчик І.Б. Аналіз сучасного стану ринку праці в Україні. Вісник ЖДТУ. Економіка, управління та адміністрування. 2015. № 1(75). С. 178-182. 


\section{References:}

1. Hnybidenko I. F., Kuznietsova N. B., Marshavin Yu. M. (2012). Rynok pratsi Ukrainy: perspektyvy yevrointehratsii: monohrafiia [Ukrainian labor market: prospects for European integration: monograph]. Kyiv. : TOV "DKS tsentr".

2. Dubych K. V. (2017). Faktory tinizatsii rynku pratsi Ukrainy [Factors of shadowing of the Ukrainian labor market]. Derzhavne upravlinnia: udoskonalennia ta rozvytok, no. 10. Available at : http://www.dy.nayka.com.ua/?op=1\&z=1132. (accessed: 20.01.2020).

3. Landsman V. A. (2012). Metodolohichni pidkhody do derzhavnoho rehuliuvannia rynku pratsi [Methodological approaches to state regulation of the labor market]. Teoriia ta praktyka derzhavnoho upravlinnia, no. 4 (39), pp. 338-345.

4. Pryimak V. I., Skorupka D. (2013). Ekonomiko-matematychni metody ta modeli v upravlinni rynkom pratsi [Economicmathematical methods and models in labor market management]. Ekonomika: realii chasu, no. 2(7), pp. 6-15.

5. Rubezhanska V. O. (2016). Funktsii ta kliuchovi napriamy upravlinnia rehionalnym rynkom pratsi [Functions and key areas of management of the regional labor market]. Ekonomika i suspilstvo, vol. 7, pp. 582-589.

6. Derzhavna sluzhba statystyky Ukrainy (2020). Rynok pratsi v 2019 rotsi [The labor market in 2019]. Available at : http://www.ukrstat.gov.ua/druk/publicat/kat_u/publ11_u.htm. (accessed: 21.01.2020).

7. Derzhavna sluzhba zainiatosti (2020). Sytuatsiia na rynku pratsi ta rezultaty diialnosti derzhavnoi sluzhby zainiatosti u 2019 rotsi: analitychna ta statystychna informatsiia [Labor Market Situation and Performance of the Public Employment Service in 2019: Analytical and Statistical Information]. Available at : https://www.dcz.gov.ua/analitics/68. (accessed: 21.01.2020).

8. Iurchyk I. B. (2015). Analiz suchasnoho stanu rynku pratsi v Ukraini [Analysis of the current state of the labor market in Ukraine]. Visnyk ZhDTU: Ekonomika, upravlinnia ta administruvannia, no. 1 (75), pp. 178-182.

\section{ЦЕЛИ ГОСУДАРСТВЕННОГО РЕГУЛИРОВАНИЯ ВНУТРЕННЕГО РЫНКА ТРУДА В УСЛОВИЯХ ИНСТИТУЦИОНАЛЬНОГО РЕФОРМИРОВАНИЯ}

Исследование посвящено обоснованию целевых ориентиров институционального регулирования развития внутреннего рынка труда, в частности структурной сбалансированности развития его сегментов и их эффективного гармонизированного взаимодействия в условиях введения институциональных реформ. Показано, что рынок труда является производным от рынка ресурсов, в значительной степени влияя на уровень развития других видов и типов внутренних рынков. Проанализированы показатели рынка труда относительно экономически активного/неактивного населения, регионального распределения рабочей силь. Предложено классификационное разделение институциионального управления общественным разделением на внутреннем рынке труда. Раскрыты и детализированы основные функиии рынка труда. Продемонстрированы характерные особенности государственного регулирования внутреннего рынка труда, которые обеспечивают сбалансированное проактивное развитие и гармонизированное взаимодействие рыночных сегментов.

Ключевые слова: государственное регулирование, трудовые ресурсы, социально-трудовые отношения, институциональные механизмы, занятость, конкурентоспособность.

\section{GOALS OF STATE REGULATION OF THE INTERNAL LABOR MARKET IN CONDITIONS OF IMPLEMENTATION OF INSTITUTIONAL REFORMS}

The study is devoted to the substantiation of the targets of institutional regulation of the development of the internal labor market. The ability of the labor market to respond timely and adequately to the dynamic processes of socio-economic transformations is a decisive condition for building an effective market mechanism for resolving social contradictions in the field of regulating social and labor relations. The need to include in the goals of the state policy of the labor market the structural balance of the development of its segments and their effective harmonized interaction requires the introduction of effective mechanisms to stimulate reproductive processes, active and effective development of structural segments of the market, which makes the relevance of this research. It has been shown that the labor market is a derivative of the resource market, significantly influencing the level of development of other types and types of domestic markets. The specificity of the labor market is manifested, first of all, by the reflection of the purchase and sale of labor through socioeconomic and labor relations. Interaction with other markets is a specific tool of the labor market, which is intended to reconcile the unit price and other conditions of interaction of the employee with the employer. Labor market indicators for economically active / inactive population and regional labor distribution are analyzed. It is noted that the unemployment rate of the able-bodied population of Ukraine is decreasing every year, which has a positive effect on the indicators of its economic activity. Involvement of labor in industrial relations is closely linked to the possibility of its reproduction as a social product, including its formation, distribution and redistribution. The classification division of institutional management of social distribution in the internal labor market is proposed. The basic functions of the labor market are revealed and detailed. The use of competition mechanisms stimulates the market to more efficient use of labor resources, which ensures the increase of profitability of economic processes and the promotion of labor resources to increase their professional and qualification level. The characteristic features of the state regulation of the internal labor market that provide balanced proactive development and harmonized interaction of market segments are demonstrated.

Key words: state regulation, labor resources, social-labor relations, institutional mechanisms, employment, competitiveness. 